DOI: 10.19195/0137-1150.167.11

\title{
KONSTANTIN BARSHT
}

Институт русской литературы РАН (Пушкинский Дом), Rosja

\section{Тема самоубийства и неевклидово пространство в творчестве Федора Достоевского}

Тема самоубийства часто звучала в русской прессе в период, когда создавались „большие” романы Федора Достоевского, в 1860-1870-е годы газеты едва ли не каждый день сообщали о таких случаях. Достоевского живо интересовала эта тема, как и все другие вопросы, связанные с нахождением человека в пороговой ситуации, между жизнью и смертью. Следует сказать, что у писателя был значительный личный опыт такого рода. В 1849 году он пережил страх смертной казни на эшафоте, в конце жизни был свидетелем казни Ипполита Млодецкого ${ }^{1}$, не раз находился на грани жизни и смерти во время ссылки. Об этом сохранились его мемуарные записи в Дневнике писателя за 1873 год [XXI, с. 133] $]^{2}$. В статье Одна из современных фальшей его Дневника писателя он передал свое „предсмертное” состояние как взрыв нравственного чувства. Видимо, именно тогда и зародилась в его сознании идея прочной определяющей связи между нравственным чувством и онтологическим состоянием человека, что и стало главным его достижением как мыслителя и художника.

И до и после Достоевского многократно говорилось о том, что самоубийца - это практический философ. Например, Альбер Камю в Мифе o Сизифе (1942) заметил, что вопрос о самоубийстве связан с „основопола-

${ }^{1}$ И. О. Млодецкий (1855-1880) совершил неудачное покушение на губернатора М. Лорис-Меликова. См. об этом: Дневник великого князя Константина Константиновича (К. Р.). 1911-1915, Москва 2013.

2 Здесь и далее произведения Ф. М. Достоевского цитируются по изданию: Ф. М. Достоевский, Полное собрание сочинений в 30 томах, Ленинград 1972-1990. Римская цифра обозначает том, арабская - страницу. 
гающим вопросом философии"3. Герои произведений Достоевского, которые намереваются свести счеты с жизнью, связывают это решение с ,вековечным вопросом" о роли и значении человека в мировой истории. Список персонажей писателя, задумывающихся о возможности суицида, практически совпадает со списком его героев-философов. Это Девушкин (Бедные люди, 1845), Голядкин (Двойник, 1846), Ордынов (Хозяйка, 1847), Мечтатель (Белье ночи, 1848), Ефимов (Неточка Незванова, 1866), Нелли (Униженные и оскорблённыл, 1861), Раскольников и Свидригайлов (Преступление и наказание, 1866), Аглая и Ипполит (Идиот, 1868), Матрёша, Кириллов и Ставрогин (Бесы, 1871-1872), Лиза (Вечнылй муж, 1870), Крафт (Подросток, 1875), Смешной (Сон смешного человека, 1877), Кроткая (Кроткая, 1876), Лиза Хохлакова (Братья Карамазовы, 1879-1880) и др. В одной из своих тетрадей писатель пометил: „Я не могу самоубийства пройти мимо. Вешаются. Грязь” [XXIII, с. 166]. Но не только „грязь”, несомненно.

В Дневнике писателя Достоевский описывал самоубийство крестьянина, который оказался не в состоянии прокормить семью [XXI, с. 143]. Он приводит и сообщение о гибели Леонида Гартунга 4 (зятя Александра Пушкина), ложно обвиненного в злоупотреблениях (в краже векселей), который не смог вынести оскорбительные подозрения и застрелился, написав, что „клянется всемогущим Богом, что ничего в этом деле не похитил и врагов своих прощает" [XXVI, с. 45]. В Подростке Достоевский обращается к судьбе бедной домашней учительницы Ольги, которая свела счеты с жизнью из-за попранного человеческого достоинства, оставив записку: „Маменька, милая, простите меня за то, что я прекратила мой жизненный дебют. Огорчавшая вас Оля" [XIII, с. 149]. Типологически сходна ей судьба Крафта, который не верил в вечную жизнь, а „временную” жизнь считал позором, который нельзя перенести [XIII, с. 134]. В Бесах Достоевский изображает попытку самоубийства негодяя Лямшина, который испугался ареста за совершенное преступление [X, с. 510], и смерть Ставрогина от осознания им окружающей бытийной пустоты [X, с. 516]. По поводу такого рода самоубийств писатель замечал, что решение возникает, когда у человека нет никакой надежды, когда ему невыносимо то, что он имеет, и он ищет другого „места” [XXI, с. 257]. По мнению писателя, это весьма распространенный протест против глупости „появления человека на земле”, реакция „на бестолковую случайность этого появления, на тиранию косной причины, с которою нельзя помириться" [XXIII, с. 145].

Важное место в осмыслении темы самоубийства занимают очерки Достоевского Два самоубийства (1876) и Приговор (1876), в которых писатель сравнивает и анализирует различные суициды — дочери Александра Гер-

${ }^{3}$ А. Камю, Творчество и свобода, пер. С. Великовский, О. Гринберг, И. Кузнецова, В. Мильчин, Москва 1990, с. 30.

${ }^{4}$ См.: „Московские ведомости” 1877, 8-14 октября. 
цена Елизаветы и бедной швеи М. Борисовой. Семнадцатилетняя Елизавета Александровна Герцен (1858-1875) покончила жизнь самоубийством во Флоренции в декабре 1875 года, отравившись хлороформом. Мотивы ссора с матерью и желание ей досадить, наряду с этим - и неразделенная любовь. Перед смертью девушка написала следующую записку5:

Предпринимаю длинное путешествие. Если самоубийство не удастся, то пусть соберутся все отпраздновать мое воскресение из мертвых с бокалами Клико. А если удастся, то я прошу только, чтоб схоронили меня, вполне убедясь, что я мертвая, потому что совсем неприятно проснуться в гробу под землею. Очень даже не шикарно выйдет [XXIII, с. 145].

В майском выпуске Дневника писателя Достоевский описывает иной вариант самоубийства, отмеченного неверием в вечную жизнь и мыслью о невыносимости пошлости обывательской жизни - акушерки Писаревой. Двадцатипятилетняя дочь состоятельных родителей, она ушла из дома и стала работать, подражая стилю поведения эмансипированных женщин. Затем она вдруг ,устала” и устала настолько, что ей захотелось „отдохнуть”: „Где же лучше отдохнешь, как не в могиле?” - комментирует писатель. Перед смертью Писарева пишет грубое, раздраженное письмо: „Не забудьте велеть стащить с меня новую рубашку и чулки, у меня на столике есть старая рубашка и чулки. Эти пусть наденут на меня". Она ругает близких: „Неужели вы верили, что я домой поеду? Ну, на кой черт я туда поеду?”. Извиняется перед хозяйкой квартиры: „...пусть простит [...] Я делаю свинство, пакость”. Дает инструкции, как хоронить: „Не давайте знать Лизаньке, а то она скажет сестре, и та приедет выть сюда. Я не хочу, чтобы надо мной выли, а родственники все без исключения воют над своими родными". Выражает сомнение в том, что получится: „Может быть, ничего не выйдет, кроме смеха. Мой вид на жительство в чемоданной крышке" [XXIII, с. 24-25].

Еще один — полярный - пример: бедная швея, которая „выбросилась из окна, из четвертого этажа, [...] держа в руках образ” [XXIII, с. 144-146]. Ее судьба позже послужила основой для сюжета рассказа Кроткая [XXIV, c. 5-35]. Заметим, что в случае с Писаревой нет никакой надежды на будущую загробную жизнь, здесь - надежда ясно выражена. Достоевский пишет:

Этот образ в руках - странная и неслыханная еще в самоубийстве черта! Это уж какое-то кроткое, смиренное самоубийство. Тут даже, видимо, не было никакого ропота или попрека: просто - стало нельзя жить, Бог не „захотел” и - умерла, помолившись [XXIII, с. 146].

Смерть Борисовой есть уход из мира существа, которое знает и чувствует свою онтологическую незыблемость в мироздании. Лиза Герцен -

${ }^{5}$ В оригинале: “Je m’en vais entreprendre un long voyage. Si cela ne reussit pas qu'on se rassemble pour feter ma resurrection avec du Cliquot. Si cela riussit, je prie qu'on ne me laisse enterrer que tout a fit morte, puisqu'il est tres desagreable de se reveiller dans un cercueil sous terre. Ce n'est pas chich" (курсив автора; XXIII, c. 145). 
уход из мира человека, который даже представить для себя не может какого-либо онтологического основания.

Главы Дневника писателя вызвали большую полемику в печати, и Достоевский был засыпан письмами, среди которых оказались и письма людей, готовых к совершению самоубийства, что породило новые рассуждения писателя в декабрьском выпуске Дневника писателя за 1876 год (Голословные утверждения, Кое-что о молодежи, О самоубийстве и о высокомерии).

6 января 1876 года Достоевский получил письмо из Киева от студента Ярошевского, „который лишил себя жизни потому только, что не смог сделаться идеально честным" [XXII, с. 313]. Ярошевский отрицал бессмертие души, одновременно с этим выражая мысль о человеколюбии, которого достаточно, „чтобы наполнить мир гармонией”6. Достоевский упрекает его в том же, что и Лизу Герцен: „В нашем самоубийце даже и тени подозрения не бывает о том, что он называется «я» и есть существо бессмертное" [XXII, c. 6].

9 июня 1876 года Достоевский получил от другого потенциального самоубийцы письмо с надписью на конверте: Confessio morituri. Основания для смерти с точки зрения автора были таковы: 1) наглый поступок природы, которая произвела его на свет, не получив предварительного согласия: „какое право она имела производить меня, без моей воли на то, сознающего?”; 2) „до целого и его гармонии мне ровно нет никакого дела после того, как я уничтожусь, - останется ли это целое с гармонией на свете после меня или уничтожится сейчас же вместе со мною"; 3) лучше быть животным, чем сознающим человеком: „сознание же мое есть именно не гармония, а, напротив, дисгармония, потому что я с ним несчастлив. Посмотрите, кто счастлив на свете и какие люди соглашаются жить? Как раз те, которые похожи на животных и ближе подходят под их тип по малому развитию их сознания”, лучше „жить как животные, то есть есть, пить, спать, устраивать гнездо и выводить детей [...] наживаться и грабить"; 4) планета не вечна, мир погибнет и „обратится в ничто, в прежний хаос. А под таким условием я ни за что не могу принять никакого счастья”, „не могу быть счастлив под условием грозящего завтра нуля"; 5) даже если грядущая гармония достижима, в законах природы явлено неуважение к человечеству: зачем „истязать человека тысячелетия, прежде чем довести его до этого счастья, одна мысль об этом уже невыносимо возмутительна"; 6) почему необходимо обратить в нуль человека, который столько сил тратит для „грядущей гармонии", несправедливо, что будущая смерть гуманно скрыта от коровы, но зачем-то дана человеку? 7) не является ли человечество жертвой садистского эксперимента: „невольно приходит в голову одна чрезвычайно забавная, но невыносимо грустная мысль: «ну что если человек был пущен на землю

${ }^{6}$ Рукописный отдел Института русской литературы РАН. Фонд 101. № 29919. ССХІб. c. 14 . 
в виде какой-то наглой пробы, чтоб только посмотреть: уживется ли подобное существо на земле или нет?»”; 8) „нахожу эту комедию, со стороны природы, совершенно глупою, а переносить эту комедию, с моей стороны, считаю даже унизительным [...] присуждаю эту природу, которая так бесцеремонно и нагло произвела меня на страдание, — вместе со мною к уничтожению" [XXIII, с. 146-148].

Обратим внимание, что доводы автора письма почти дословно повторяют предсмертную записку Ипполита Терентьева, героя романа Идиот, написанного Достоевским восемью годами ранее. Подобно безвестному NN, герой Достоевского возмущается несправедливостью законов природы, согласно которым сознанию человека „предписано этою высшею силой уничтожиться [...] и даже без объяснения для чего". Ипполит цитирует Монтеня: „Если б я имел власть не родиться, то наверно не принял бы существования на таких насмешливых условия “" [VIII, с. 344]. Подобно NN, Ипполит выражает протест против того, что природа наложила на него такие ограничения, в результате: „может быть, самоубийство есть единственное дело, которое я ещё могу успеть начать и окончить по собственной воле моей" [VIII, c. 344]. Временное существование неприемлемо для Достоевского и героев его произведения, самоубийство - протест против издевательства над вечной душой человека, заключенной во временные рамки. Для Ипполита и NN мир природы есть ад, в котором с немыслимой жестокостью потенциально вечная сущность человека заключена во временную оболочку тела.

Заметим, что к той же мысли - о земном мире как фактическом аде приходил и сам Достоевский в юные годы. В семнадцатилетнем возрасте он писал брату:

Не знаю, стихнут ли когда мои грустные идеи? Одно только состоянье и дано в удел человеку: атмосфера души его состоит из слиянья неба с землею; какое же противузаконное дитя человек; закон духовной природы нарушен. [...] Мне кажется, что мир наш - чистилище духов небесных, отуманенных грешною мыслию. Мне кажется, мир принял значенье отрицательное [XXVIII, с. 50].

Мысль о „земном аде” прямо вытекает из идеи о несовершенстве устройства мира, в котором зло является его органической частью. Мысль о том, что мир есть ад, впервые была сформулирована в зороастризме. Согласно этой концепции, после смерти человека ждет небесный суд, где боги взвешивают количество добрых и злых поступков, с тем чтобы распределить души, направив их в рай, ад или чистилище. Но земное существование человека проходит в тюрьме - трехмерном пространстве с однонаправленным временем, а Земля - самая ужасная камера этой тюрьмы. В ней мучается заключенная в тело и отделенная от Бога человеческая душа. В Братьях Карамазовых Иван оспаривает мысль, что зло вторично и управляемо

7 „Жизнь зависит от чужой воли, смерть же - только от нашей” (М. Монтень, Onblmbl. В 3 книгах, пер. А. Бобович, Ф. Коган-Бернштейн, Н. Рыкова, Москва 1979, кн. 1, с. 308). 
со стороны Бога, а в Провидении зло преобразуется в добро ${ }^{8}$. Иван возвращает своей „билет” в рай, потому что не желает видеть, как там убийца будет обниматься с жертвой. Герой говорит:

Перенести я притом не могу, что иной, высший даже сердцем человек и с умом высоким, начинает с идеала Мадонны, а кончает идеалом содомским. [...] Тут дьявол с Богом борется, а поле битвы - сердца людей [XIV, с. 100].

Данная формула есть типичная гностическая конструкция, идея жизни человека подается как процесс выбора между добром и злом, онтологическое самоопределение человека идет по линии приобщения к созидательным целям Космоса или по линии следования силам разрушения и уничтожения.

В главе О Большой и Малой Медведицах, о молитве великого Гете и вообще о дурных привычках, входящей в Дневник писателя, Достоевский называет „свинством” отсутствие у человека „гамлетовского вопроса” о том, „что будет там” [XXII, с. 6] и называет это состояние „безмыслием”:

Я говорю безмыслие, а не бессмыслие. Ну, не верь, но хоть помысли. В нашем самоубийце даже и тени подозрения не бывает о том, что он называется я и есть существо бессмертное. Он даже как будто никогда не слыхал о том ровно ничего. И, однако, он вовсе и не атеист. Вспомните прежних атеистов: утратив веру в одно, они тотчас же начинали страстно веровать в другое. Вспомните страстную веру Дидро, Вольтера... У наших — полное tabula rasa [XXII, с. 5-6].

В художественных произведениях писатель создает реестр нравственно-оправданных самоубийств, каждое из которых определяет тот или иной вариант конструкции Мироздания. Философами-самоубийцами Достоевского руководят нравственно-онтологические основания. Тема самоубийства в романах Достоевского открывает спектр вариантов постановки вопроса о смысле и цели существования человека и человечества ${ }^{9}$. Суть в том, чтобы понять смысл этих ответов как философский вызов. Основная мысль, которую проводит Достоевский, — это необходимость и реальность „высшей идеи существования”, существования одновременно и в нашем мире, и за его пределами во времени и в вечности. Согласно мысли писателя, стремление к обретению этой идеи возрастает в катастрофические периоды жизни общества, становится необходима „потребность «высшей мысли» и «высшей жизни»". И у атеиста, и у верующего в равной степени „манит жаждущую веры душу к небесам”. Более того, согласно мнению писателя, именно отрицатели загробной жизни выражают максимум стремления к ,положительному подтверждению” [XXIV, с. 334].

8 „Но в руках Провидения все обращается в благо, дабы многоразличная премудрость Божия, столь удивительно проявляющаяся в разнообразии дел Божиих по предвечному совету, пополнившемуся во Христе, открывалась особенно в церкви Его" (Еф., ІІІ, 10, 11).

9 „Почти все убийства и самоубийства в романах Достоевского — идеологичны” (И. Л. Волгин, Последний год Достоевского, Москва 2010, с. 38). 
Главное открытие Достоевского: онтология — вовсе не отвлеченная схоластика, она есть нравственность, но наследованная не от человека к человеку, а от человека к Вселенной. Бытие человека определяется его нравственным состоянием; мера ответственности за окружающее соответствует качеству бытия. Степан Трофимович Верховенский в Бесах восторгается перед смертью мыслью из Апокалипсиса: „Знаю твои дела; ты ни холоден, ни горяч; о, если б ты был холоден или горяч! Но поелику ты тепл, а не горяч и не холоден, то извергну тебя из уст моих" [Откр. 3: 15-16], называя эту мысль „великой” [X, с. 497-498]. Согласно мнению Достоевского,

самоубийство, при потере идеи о бессмертии, становится совершенною и неизбежною даже необходимостью для всякого человека, чуть-чуть поднявшегося в своем развитии над скотами. Напротив, бессмертие, обещая вечную жизнь, тем крепче связывает человека с землей. Тут, казалось бы, даже противоречие: если жизни так много, то есть кроме земной и бессмертная, то для чего бы так дорожить земною-то жизнью? А выходит именно напротив, ибо только с верой в свое бессмертие человек постигает всю разумную цель свою на земле. Отсюда обратно и нравоучение моей октябрьской статьи: „Если убеждение в бессмертии так необходимо для бытия человеческого, то, стало быть, оно и есть нормальное состояние человечества, а коли так, то и самое бессмертие души человеческой существует несомненно" [XXIV, с. 49].

О статье Приговор Достоевский говорит о доказательстве той „самой высшей идеи человеческого бытия”, которая предполагает „необходимость и неизбежность убеждения в бессмертии души человеческой [...] без веры в свою душу и в ее бессмертие бытие человека неестественно, немыслимо и невыносимо" [XXIV, с. 46]. Эти идеи о несовершенстве временной социально-природной действительности и представление о вечной и совершенной Вселенной заставляют обратиться к теме параллельного мира, в котором пребывает, одновременно с нашим миром, духовная сущность человека.

Согласно воспоминаниям Александра Мошковского, Альберт Эйнштейн говорил следующее: „Достоевский дал мне больше, чем любой мыслитель, больше, чем Гаусс!"”10. Заметим, Эйнштейн высказывался о Братьях Kapaмaзовыx: „Мне нет надобности заниматься для этого литературным анализом или исследовать какие-нибудь психологические тонкости - ведь все равно все подобные исследования никогда не проникнут в ядро такого творения, как Братья Карамазовы""11. В другом случае Эйнштейн заметил: „Достоевский показал нам жизнь, это верно; но цель его заключалась в том, чтобы обратить наше внимание на загадку духовного бытия" ${ }^{2}$. Ответ находится там же, где и ключ к пониманию смысла жизни и смерти, ее начала

10 А. Мошковский, Альберт Эйнштейн. Беседы с Эйнштейном о теории относительности и общей системе мира, Москва 1922, с. 162.

11 Там же, с. 164.

12 А. Эйнштейн, Собрание научных трудов, т. 4, Москва 1967, с. 164. См. также: Б. Г. Кузнецов, Эйнштейн. Жизнь. Смерть. Бессмертие, Москва 1980. 
и конца, заключенного в романе Братья Карамазовы. В 1870-е годы Достоевский пришел к представлению о том, что наш мир, воспринимаемый пятью органами чувств, есть лишь небольшая часть действительности; наша телесность укоренена в трехмерном мире со стрелой времени, в то время как духовная сущность простирается за пределы четырехмерного континуума, в пятое измерение, доступное лишь интуитивному восприятию. Он записывает в тетради:

Если б где в мире был конец, то был бы всему миру конец. Параллелизм линий. Треугольник, слияние в бесконечности, одна квадрильонная все-таки ничтожность перед бесконечностью. В бесконечности же параллельные линии должны сойтись. Ибо все эти вершины треугольника все-таки в конечном пространстве, и правило, что чем бесконечнее, тем ближе к параллелизму, должно остаться. В бесконечности должны слиться параллельные линии, но - бесконечность эта никогда не придет. Если б пришла, то был бы конец бесконечности, что есть абсурд. Если б сошлись параллельные линии, то был бы конец миру и геометрическому закону и Богу, что есть абсурд, но лишь для ума человеческого. Реальный (созданный) мир конечен, невещественный же мир бесконечен. Если б сошлись параллельные линии, кончился бы закон мира сего. Но в бесконечности они сходятся, и бесконечность есть несомненно. Ибо если б не было бесконечности, не было бы и конечности, немыслима бы она была. А если есть бесконечность, то есть Бог и мир другой, на иных законах, чем реальный (созданный) мир [XXVII, с. 43].

Другими словами, речь идет о том, что человек живет в нескольких совмещенных пространствах — четырехмерном континууме, доступном нашим органам чувств, и в многомерном континууме, находящемся за пределами нашего восприятия, но столь же реальном и существенном. Часть существа человека пребывает в многомерном вечном мире, который и обеспечивает его онтологический статус, тот самый, отсутствие которого приводит к гибели Ипполита Терентьева (Идиот) и других персонажей Достоевского, а также NN, написавшего письмо Достоевскому. Мысль эту проводит в Братьях Карамазовых Иван:

Вот, однако, что надо отметить: если Бог есть и если он действительно создал землю, то, как нам совершенно известно, создал он ее по эвклидовой геометрии, а ум человеческий с понятием лишь о трех измерениях пространства. Между тем находились и находятся даже и теперь геометры и философы, и даже из замечательнейших, которые сомневаются в том, чтобы вся вселенная или, еще обширнее - всё бытие было создано лишь по эвклидовой геометрии, осмеливаются даже мечтать, что две параллельные линии, которые, по Эвклиду, ни за что не могут сойтись на земле, может быть, и сошлись бы где-нибудь в бесконечности [XIV, с. 214].

Комментарием к рассуждениям Достоевского в первом случае и Ивана Карамазова во втором может быть история создания неевклидовой геометрии, которая отвергла доктрину о том, что сумма углов треугольника равна двум прямым углам, а через точку вне прямой можно провести только одну параллельную ей прямую. Была доказана реальность геометрии, в которой сумма углов треугольника меньше или больше двух прямых углов, а через 
точку вне прямой можно провести либо множество, либо ни одной параллельной ей прямой, где перпендикуляры к прямой расходятся или сходятся в одной точке. Тем самым, были перевернуты представления о формате Вселенной, оказалось, что пространство способно сдвигаться и искривляться, меняя свои характеристики. Эти идеи впервые высказали Николай Лобачевский (1829) и Янош Бойаи (1832). Выстраивая картину мира, Эйнштейн в Теории относительности осмыслял данные идеи на двух уровнях - непосредственно в опоре на научные работы Лобачевского, Бойаи и Римана, а также преломленными в художественном мире Братьев Kapaмaзовых. Последнее, видимо, произвело на него особое впечатление.

Достоевский мог познакомиться с подобными идеями по мемуарно-биографическим изданиям, вышедшим после смерти Лобачевского в 1856 году, где описывались научные достижения ученого ${ }^{13}$. Возможно, он мог познакомиться с работами Лобачевского 1830-х годов и в студенческие годы, когда изучал геометрию и математику в Главном инженерном училище ${ }^{14}$. Теория Римана была опубликована только в 1868 году, и, начиная с этого момента, неевклидова геометрия стала идеей, захватившей русское общество, в т. ч. писателей, философов, публицистов. Продвигая эту концепцию, Георг Фридрих Бернхард Риман в 1850-е годы сделал ряд выводов философского плана и установил, что неевклидовы пространства не имеют ограничений в количестве измерений. Далее те же идеи, уже за пределами жизненного пути Достоевского, развивал Герман Минковский, доказавший, что течение времени связано с пространственными измерениями, формирующими новую геометрическую конструкцию, пространственно-временной континуум.

Сравнивая Достоевского с Карлом Фридрихом Гауссом (1777-1855), родоначальником „дифференциальной геометрии” (геометрии искривленных плоскостей) и последователем идей Лобачевского, Эйнштейн указал на то, что именно привлекло его внимание в романе Братья Карамазовы. Идея Лобачевского-Гаусса-Римана опровергла концепцию плоского пространства, заповеданную Евклидом, возникла геометрия Вселенной, в которой нормой является искривленное пространство, меняющее свойства вещей и течение времени. Исходя из представления о том, что человек некоей своей частью укоренен в пятом или $\mathrm{N}$ измерении, Достоевский был уверен, что на кривизну пространства влияет нравственное состояние человека. Идею связи между свойствами времени и пространства, зависимыми от нравственного статуса людей, своеобразную модель неевклидовой геометрии, Достоевский реализовал в Братьях Карамазовых, на уровне хроното-

13 См.: А. Ф. Попов, Воспоминание о службе и трудах профессора Казанского университета Лобачевского, Санкт-Петербург 1857; Э. П. Янишевский, Историческая записка о жизни и деятельности Н. И. Лобачевского, Казань 1868.

${ }^{14}$ Н. И. Лобачевский, Воображаемая геометрия, Казань 1835; его же, Применение воображаемой геометрии к некоторым интегралам, Казань 1836. 
па художественного мира и в идеологических штудиях Ивана Карамазова, настаивавшего на необходимости связи между пространственным расположением человека в реальности двух совмещенных миров, временном и вечном, евклидовом и неевклидовом, между местом человека в бытии и его нравственным статусом. Согласно идее, которая владела Достоевским в период создания романа Братья Карамазовы, скрытая от нашего восприятия часть Вселенной оказывает огромное неконтролируемое влияние на физические процессы в воспринимаемой нами реальной действительности ${ }^{15}$.

По мнению Евгении Кийко, писатель познакомился с неевклидовой геометрией по статье Германа Гельмгольца (1821-1894) O происхождении и значении геометрических аксиом ${ }^{16}$. В этом популярном журнале систематически печатались новости науки. Замечательно то, что журнал был склонен к публикации материалов эзотерического характера (Наука и метафизика, Физиологические объяснения некоторых явлений спиритизма и др.) Обращаясь к читателям, Гельмгольц писал: „Задачей настоящей статьи является обсуждение философского значения новейших изысканий в области геометрических аксиом и обсуждение возможности создания аналитическим путем новых систем геометрии с иными аксиомами, чем у Эвклида"17. В статье детально излагаются принципы строительства неевклидовой геометрии Лобачевского, а затем Бельтрами и Римана.

Беседуя с чертом, Иван Карамазов вступает в обсуждение нескольких проблем современной физики, в частности, того, что будет с топором в роли спутника Земли в условиях абсолютного нуля [XV, с. 75]. Отвечая на вопрос, приходилось ли ему встречаться и искушать святых, черт подтверждает идею многомирия Вселенной и существование бессмертной личности человека, расположенной в нескольких мирах: „Весь мир и миры забудешь, а к одному этакому прилепишься, потому что бриллиант-то уж очень драгоценен" [XV, с. 80]. Достоевский был уверен, что сверхмир (пятое измерение и далее) существует, его существование оправдывает реальность чуда, писатель говорит о „фантастической реальности”, и его герой понимает, что ,если есть другие миры и если правда, что человек бессмертен, то есть и сам из других миров, то, стало быть, есть и всё, есть связь с другими мирами” [XV, с. 201]. Герои-философы Достоевского, поразившись „убеж-

15 Е. И. Кийко, Восприятие Достоевским неэвклидовой геометрии, [в:] Достоевский. Материалы и исследования, т. 6, Ленинград 1985, с. 120-128.

16 „Знание” 1876, № 8. Помимо этого Достоевскому были доступны издания: В. Л. Розенберг, О зрении человека. (Излож. попул. по Гельмгольиу В. Розенбергом), Одесса 1866; [Г. Л. Ф. Гельмгольц], Закон сохранения силь д-ра Гельмгольиа, проф. физиологии в Гейдельбергском ун-те. Лекиии, читанные им в Лондоне в Royal Institution, пер. с англ. Дм. Рындовский, Харьков 1865; [Г. Л. Ф. Гельмгольц], Популярные научные статьи Г. Гельмгольиа, орд. проф. физиологии при Гейдельбергском ун-те, вып. 1, Санкт-Петербург 1866.

${ }^{17}$ См.: Е. И. Кийко, Восприятие Достоевским неэвклидовой геометрии..., с. 122. 
дением, что бессмертие и Бог существуют”, говорят себе: „Хочу жить для бессмертия, а половинного компромисса не принимаю" [XIV, с. 25].

Важность философского достижения Достоевского в том, что он не только по-новому интерпретировал философский смысл геометрии Лобачевского-Римана, но и осознал значение связи между нравственным и онтологическим статусом человека в мироздании. Поэтому представления о добре и зле, справедливости и грехе, взятые в пределах многомерного мира, будут иметь иные смыслы, иные значения, в сравнении с тем, как они выглядят в трехмерном мире. Следуя этой мысли, Иван Карамазов допускает, что его „земной, эвклидовский” ум искажает истинную картину нравственного состояния человечества, неверно трактует факты, и потому его моральные штудии — „это лишь эвклидовская дичь, ведь я знаю же это, ведь жить по ней я не могу же согласиться!” [XIV, с. 222]. Фактически Иван требует, чтобы в четырехмерном континууме действовали те же законы, которые актуальны для многомерного большого мира, в котором человек укоренен лишь малой своей частью. Одновременно герой понимает, что в рамках большого многомерного мира действует иная логика, однако издевательство над человеком, помещенным в трехмерную реальность со стрелой времени, также не может принять: „Я не Бога не принимаю [...] мира, им созданного [...] не принимаю и не могу согласиться принять [...] Пусть даже параллельные линии сойдутся и я это сам увижу [...] и не приму” [XIV, с. 214-215].

Иван, как и автор, понимает, что земная телесная жизнь человека лишь небольшой отрезок жизненной протяженности, так как измерений мироздания много, больше доступных нам четырех. Это объясняет все, включая время и бессмертие, и придает особый смысл самоубийству человека, верующего в существование вечности. Понятие о Духе Святом в этих условиях обретает особый смысл, и мы видим его в религиозно-философских концепциях Достоевского, в конце жизни вырабатывавшего символ веры Нового христианства, альтернативного Православию. Реальность многомирия и многомерного пространства-времени заставляет предположить иную структуру человеческого „я”, которое, вероятно, может существовать одновременно в нескольких точках отсчета. В таком случае жизнь „пробегающая через материю" (А. Бергсон) обладает дополнительной онтологической устойчивостью, переключаясь с одной точки на другую в момент физической смерти. Покончивший со своею жизнью человек будет думать: вот он я, ведь ничего не случилось.

Таким образом, по Достоевскому, человек наделен бытийным стержнем, пронизывающим многие слои бытия и измерения пространства. Глубина укорененности в мироздании зависит от нравственного статуса, который проявляется в мере ответственности за собственную жизнь и жизнь другого. Иисуса Христа писатель понимал как вечное „я”, которое пронизывает все уровни бытия, от самого низа до самого верха. Мысль о духовном возвышении человека, которая занимала Достоевского всю жизнь, есть, фак- 
тически, мысль о его онтологическом спасении. Лишь на достаточно высоком уровне развития, соприкасаясь с пятым измерением, человек начинает слышать голос истины (интуиция Бергсона, евангельский Дух святой, категорический императив Канта, „амулет” Паскаля). В Дневнике писателя за 1876 год Достоевский записал:

Что может быть фантастичнее и неожиданнее действительности? Что может быть даже невероятнее иногда действительности? Никогда романисту не представить таких невозможностей, как те, которые действительность представляет нам каждый день тысячами, в виде самых обыкновенных вещей [XXII, с. 91].

Нравственное состояние человека есть ключ к его онтологическому спасению, однако понимание этого доступно лишь спасшимся. Как разорвать эту дилемму, Достоевский не знал. Но на новом уровне бытия человечество ждет новая жизнь, в которой состоится „перемена земли и человека физически [...] И мир переменится, и дела переменятся, и мысли, и все чувства" [X, с. 94]. Кириллов (Бесbl) говорит о том, что бессмертие существует уже сейчас, в земной жизни, и самоубийство есть лишь отказ от неважной части собственного материального владения, не самого лучшего, даже обременительного. Новый человек живет на более высоком онтологическом уровне других измерений.

В Сне смешного человека концепция онтологической широты человека не просто намечена, но описана как путь в другие измерения, и здесь же дается указание на то, что возможен нравственный подвиг, который может сдвинуть людей к вечному бытию, к онтологической правде жизни в нескольких измерениях. Ушедший в иные миры самоубийца требует от жителей планеты Эдем, впавших в грех, чтобы они распяли его на кресте, тем самым пытаясь спасти и себя от небытия [XXV, с. 117]. В произведении звучит мысль, что посмертное измерение Смешного - не единственное, может быть, за ним маячит и следующее.

Достоевский не был оригинален в том, что предполагал наличие нескольких миров и связывал онтологический статус человека и его нравственное состояние - подобные суждения можно проследить во многих религиозно-философских конструкциях. Но новизна его идеи в том, что он не разделял жизнь человека на части, до и после гроба, обнаруживая многослойность бытия, устроенного по принципу луковицы, когда каждому нижнему слою не доступен верхний, находящийся над ним. Почему Достоевский увлекся идеей неевклидовой геометрии и что понравилось Эйнштейну в Братьях Карамазовых? Мысль, что бессмертие существует уже сейчас, а жизнь человека на Земле есть лишь малая часть его бытия, не определяемая стрелой времени: „времени не будет”, говорит Ипполит (Идиот), цитируя Апокалипсис ${ }^{18}$.

18 ,и клялся Живущим во веки веков, Который сотворил небо и все, что на нем, землю и все, что на ней, и море и все, что в нем, что времени уже не будет” (Откр. 10: 6); „И даны были 
Таким образом, Достоевский нашел в неевклидовой геометрии перспективу преодоления зла, решение вопроса о трагическом состоянии человека на Земле, которое приводит человека к решению покончить с жизнью. Зло лишь на низших ступенях многослойного мироздания выглядит непреодолимым, „но знает Бог, что в день, в который вы вкусите их, откроются глаза ваши, и вы будете, как боги, знающие добро и зло" (Бытие. 3: 5). Эти вопросы Достоевский и положил в основание рассуждений Ивана, Кириллова и других персонажей о возможности преодоления зла временного существования человека.

\section{Библиография}

Волгин И. Л., Последний год Достоевского, Москва 2010.

[Гельмгольц Г. Л. Ф.], Закон сохранения силь д-ра Гельмгольиа, проф. физиологии в Гейдельбергском ун-те. Лекиии, читанные им в Лондоне в Royal Institution, пер. с англ. Дм. Рындовский, Харьков 1865.

[Гельмгольц Г. Л. Ф.], Популярные научные статьи Г. Гельмгольияа, орд. проф. физиологии при Гейдельбергском ун-те, вып. 1, Санкт-Петербург 1866.

Дневник великого князя Константина Константиновича (К. Р.). 1911-1915, Москва 2013.

Достоевский Ф. М., Полное собрание сочинений в 30 томах, Ленинград 1972-1990.

Камю А., Творчество и свобода, пер. С. Великовский, О. Гринберг, И. Кузнецова, В. Мильчин, Москва 1990.

Кийко Е. И., Восприятие Достоевским неэвклидовой геометрии, [в:] Достоевский. Материалы и исследования, т. 6, Ленинград 1985.

Кузнецов Б. Г., Эйнштейн. Жизнь. Смерть. Бессмертие, Москва 1980.

Лобачевский Н. И., Воображаемая геометрия, Казань 1835.

Лобачевский Н. И., Применение воображаемой геометрии к некоторым интегралам, Казань 1836.

Монтень М., Onblmbl. В 3 книгах, пер. А. Бобович, Ф. Коган-Бернштейн, Н. Рыкова, Москва 1979.

Мошковский А., Альберт Эйнштейн. Беседы с Эйнштейном о теории относительности и общей системе мира, Москва 1922.

Попов А. Ф., Воспоминание о службе и трудах профессора Казанского университета Лобачевского, Санкт-Петербург 1857.

Розенберг В. Л., О зрении человека. (Излож. попул. по Гельмгольиу В. Розенбергом), Одесса 1866.

Эйнштейн А., Собрание научных трудов. $B 4$ т., Москва 1967.

Янишевский Э. П., Историческая записка о жизни и деятельности Н. И. Лобачевского, Казань 1868.

жене два крыла большого орла, чтобы она летела в пустыню в свое место от лица змия и там питалась в продолжение времени, времен и полвремени” (Откр. 12: 14). 


\section{The theme of suicide and the non-Euclidean space in the works of Fyodor Dostoevsky}

Summary

The article proposes a hypothesis about the relation between the ethical imperative, inscribed in those Fyodor Dostoyevsky's heroes-philosophers, who are seeking answers to the "eternal question" about the meaning and purpose of life, and their attempts to overcome Homo Sapiens limitations with the suicide and non-Euclidean geometry, which Dostoevsky met in the 1870s in the Hermann Helmholtz's works. In the writer's works was formulated an existential idea, exceeding the boundaries of possibilities, the width of man, ontologically rooted in parallel worlds, existing beyond our four-dimensional continuum, in the fifth and other dimensions. The most important thesis of Dostoevsky's philosophy, the personal immortality of man, which was developed by the writer throughout all his works, based on the data of modern science, received a new justification. This, next, enabled the strengthening of philosophical basis for the writer's favorite concept about the direct connection between the moral and ontological status of a human being, which only makes sense if it is possible to remain in the eternity.

Keywords: Dostoyevsky, suicide, eternal being, ethical-ontological status, time and space, non-Euclidean geometry

\section{Motyw samobójstwa i przestrzeń nieeuklidesowa w twórczości Fiodora Dostojewskiego}

\section{Streszczenie}

W artykule wysunięto hipotezę o związku pomiędzy imperatywem etycznym, wpisanym w szukanie odpowiedzi na „odwieczne pytanie” o sens i cel życia ludzkiego przez bohaterówfilozofów Fiodora Dostojewskiego, a ich próbami przezwyciężenia bytowego ograniczenia Homo sapiens za pomocą samobójstwa i geometrii nieeuklidesowej, którą Dostojewski poznał w latach siedemdziesiątych XIX wieku z dzieł Hermanna von Helmholtza. W twórczości pisarza sformułowała się idea egzystencjalnej, przekraczającej granice możliwości, bytu człowieka, ontologicznie zakorzenionego w światach równoległych, istniejących poza naszym czterowymiarowym kontinuum, w piątym i innych wymiarach. Najważniejsza teza filozofii Dostojewskiego: osobista nieśmiertelność człowieka, rozwijana przez pisarza we wszystkich jego dziełach, dzięki ustaleniom współczesnej nauki otrzymała nowe uzasadnienie. To z kolei umożliwiło ugruntowanie filozoficznej podstawy ulubionej koncepcji pisarza o bezpośrednim związku między moralnym i ontologicznym statusem człowieka, mającej sens tylko w wypadku możliwości pozostania w wieczności.

Słowa kluczowe: Dostojewski, samobójstwo, istota wieczna, status etyczno-ontologiczny, czas i przestrzeń, geometria nieeuklidesowa 